\title{
COMPARATIVE ANALYSIS OF DAIRY FARMING MANAGEMENT AND BUSINESS MODEL BETWEEN EAST JAVA AND WEST JAVA, INDONESIA
}

\author{
Siti Jahroh ${ }^{* 1}$, Juniar Atmakusuma ${ }^{* *}$, Harmini ${ }^{* *)}$, and Achmad Fadillah ${ }^{*)}$ \\ *) School of Business, IPB University \\ Jl. Raya Padjajaran, Bogor 16151, Indonesia \\ ${ }^{* *}$ Department of Agribusiness, Faculty of Economics and Management, IPB University \\ Jl. Kamper Wing 4 Level 5 Kampus IPB, Dramaga16680 Bogor, Indonesia
}

\begin{abstract}
Milk is an essential commodity because the Government of Indonesia aimed to increase domestic milk production up to $50 \%$ by 2020 . At the present, domestic milk production in Indonesia is only able to fulfill $20 \%$ of national milk demand. East Java and West Java Provinces are the main producers of milk in Indonesia. The objective of this study was to compare dairy farming management and business model between East Java and West Java, Indonesia. This study employed descriptive statistical and quantitative analyses. The dairy farming management questionnaire survey was conducted in May-July 2016 and the dairy business model survey was conducted in October-November 2018. There were no significant differences in dairy farming activities between farmers in Lembang and Malang whereas the average number of lactating cows is 5 and 3 heads, respectively. Farmers received farm gate price of Rp4,622 per liter in Lembang and Rp4,535 per liter in Malang. Based on net return over cash variable cost, farmers in Malang and Lembang earned around 20 percent from the milk price. There were six inclusive business models (IBMs) identified between smallholder farmers, cooperatives, and private companies with different characteristics have been implemented in East Java and West Java. It is suggested that cooperative improves its role in the integrated agribusiness system in order to improve the bargaining position of dairy farmers as well as in terms of cost-efficiency. The strategies and policies should be implemented to support development of sustainable, profitable and smallholder-inclusive dairy supply chains in East Java and West Java.
\end{abstract}

Keywords: inclusive business model, integrated agribusiness system, dairy farming, milk production, net return

\begin{abstract}
Abstrak: Susu merupakan komoditas penting bagi Indonesia karena pemerintah memiliki program untuk meningkatkan produksi susu nasional hingga 50\% pada tahun 2020. Saat ini, produksi susu di Indonesia hanya mampu memenuhi $20 \%$ dari permintaan susu nasional. Provinsi Jawa Timur dan Jawa Barat adalah dua produsen utama susu di Indonesia. Tujuan dari penelitian ini adalah untuk menganalisis perbandingan manajemen peternakan sapi perah dan model bisnisnya antara Jawa Timur dan Jawa Barat, Indonesia. Metode yang digunakan adalah analysis statistika deskriptif dan kuantitatif. Survei kuesioner manajemen peternakan sapi perah dilakukan pada Mei-Juli 2016 dan survei model bisnis susu dilakukan pada Oktober-November 2018. Hasil studi menunjukkan bahwa tidak ada perbedaan signifikan dalam kegiatan peternakan sapi perah antara peternak di Lembang, Jawa Barat dan Malang, Jawa Timur dengan rata-rata jumlah kepemilikan sapi perah adalah 5 ekor dan 3 ekor per peternak untuk masing-masing wilayah. Peternak mendapatkan harga sebesar Rp4.622 per liter di Lembang dan Rp4.535 per liter di Malang. Berdasarkan analisis net return over cash variable cost, peternak di Malang dan Lembang memperoleh sekitar 20 persen dari harga susu. Ada enam model bisnis inklusif (inclusive business model/IBM) yang diidentifikasi dari peternak, koperasi, dan perusahaan swasta dengan karakteristik yang berbeda dan telah diterapkan di Jawa Timur dan Jawa Barat. Hasil penelitian ini menyarankan agar koperasi meningkatkan perannya dalam sistem agribisnis terpadu untuk meningkatkan posisi tawar peternak sapi perah serta efisiensi biaya. Strategi dan kebijakan harus diterapkan untuk mendukung pengembangan rantai pasok susu yang berkelanjutan, menguntungkan, dan inklusif bagi peternak di Jawa Timur dan Jawa Barat.
\end{abstract}

Kata kunci: model bisnis inklusif, sistem agribisnis terpadu, peternakan sapi perah, produksi susu, net return,

\footnotetext{
${ }^{1}$ Corresponding author:

Email: sitijahroh@gmail.com
} 


\section{INTRODUCTION}

Milk is an essential commodity where the Government of Indonesia aimed to increase domestic milk production up to $50 \%$ by 2020 . At the present, domestic milk production in Indonesia is only able to fulfill $20 \%$ of national milk demand. The dairy industry in Indonesia has shown an increase in domestic consumption of milk and its derivative products. This trend is driven by increasing population, people's awareness of healthy life and increasing per capita income (USD 3,605/ capita) in 2016 which it increased 5.02\% (Statistics Indonesia, 2017). Consumption of milk tend to increase about $4.1 \%$ per year from 2017 to 2020 (Secretariat General of Ministry of Agriculture 2016). However, the dairy market in Indonesia is still heavily reliant on imported milk products, with $79 \%$ imported from overseas. The growth of national milk production is about 3\% each year. Therefore, Indonesia imported (79\%) to meet the consumption (Secretariat General of Ministry of Agriculture 2016).

The dairy cattle population is concentrated in Java Island, which the percentage reached $99 \%$ of the total dairy cattle population in Indonesia. East Java, Central Java, and West Java provinces have the largest number of dairy cattle population in Indonesia. In 2016, the total number of dairy cattle in East Java, Central Java, and West Java were 264,905 (49.7\%), 137,434 (25\%), and 119,287 (22.93\%), respectively. The detailed number of dairy cattle in Indonesia from 2012 to 2016 can be seen in Table 1.

Over the last few years, the Indonesian dairy industry has been expanding to meet the increasing demand for milk and dairy products. Indonesian milk production has increased by $8.4 \%$ (2013-2016) to reach 852,951 tons in 2016. East Java and West Java provinces are the two largest milk producers among all Indonesian provinces (Figure 1). In 2016, the total number of milk production in East Java and West Java were 481,399 tons and 256,206 tons, respectively. East Java contributed around $56.4 \%$ of the total national milk production, followed by West Java with around 30\% to the national milk production in 2016.

Indonesia's dairy industry is dominated by smallholder farmers. Farm sizes are typically small, with farms, on average, owning less than five milking cows (Guntoro et al. 2016). In 2012, Indonesia was producing less than one-third of its domestic demand for dairy products. That has contracted further in recent years. The fragility of local milk supply within Indonesia was demonstrated during 2014 when approximately $40 \%$ of the nation's dairy herd was slaughtered due to high beef prices.

The central and local governments of Indonesia considered that the dairy industry was an industry that has the potential to increase the income and welfare of farmers. The governments also view the dairy industry can be as a tool to increase employment opportunities, especially in the rural areas. In a national context, the Indonesian dairy industry can play a role in improving the country's economy and facing dairy international trade competition (Riethmuller, 1999). The Government of Indonesia (GoI) is investing substantial resources into the nation's dairy sector, aiming to increase domestic production. In 2012 Indonesia was producing less than one-third of its domestic demand for dairy products (Umberger et al., 2016). The government collaborated with large companies using a foreign investment scheme program to develop the milk processing industry. Milk processing industry (MPI) has been used raw material milk bought from international markets before the Indonesian government sets the regulation that MPI should use local raw material milk (Riethmuller, 1999).

Table 1. Number of dairy cattle in Indonesia from 2012 to 2016

\begin{tabular}{|c|c|c|c|c|c|c|c|}
\hline \multirow[t]{2}{*}{ Province } & \multicolumn{5}{|c|}{ Number of Cattle (head) } & \multirow{2}{*}{$\begin{array}{l}\text { Average } \\
\text { (head) }\end{array}$} & \multirow{2}{*}{$\begin{array}{c}\text { Contribution } \\
(\%)\end{array}$} \\
\hline & 2012 & 2013 & 2014 & 2015 & 2016 & & \\
\hline East Java & 308,841 & 222,910 & 245,246 & 255,947 & 264,905 & 259,570 & 49.70 \\
\hline West Java & 136,054 & 103,832 & 123,140 & 116,400 & 119,287 & 119,743 & 22.93 \\
\hline Central Java & 154,398 & 103,794 & 122,566 & 134,670 & 137,434 & 130,572 & 25.00 \\
\hline DI Yogyakarta & 3,934 & 4,326 & 3,990 & 4,044 & 4,066 & 4,072 & 0.78 \\
\hline DKI Jakarta & 2,775 & 2,686 & 2,638 & 2,433 & 2,603 & 2,627 & 0.50 \\
\hline Provinces outside of Java & 5,938 & 6,718 & 4,936 & 5,154 & 5,565 & 5,662 & 1.08 \\
\hline Indonesia & 611,939 & 444,266 & 502,516 & 518,649 & 533,860 & 522,246 & 100.00 \\
\hline
\end{tabular}




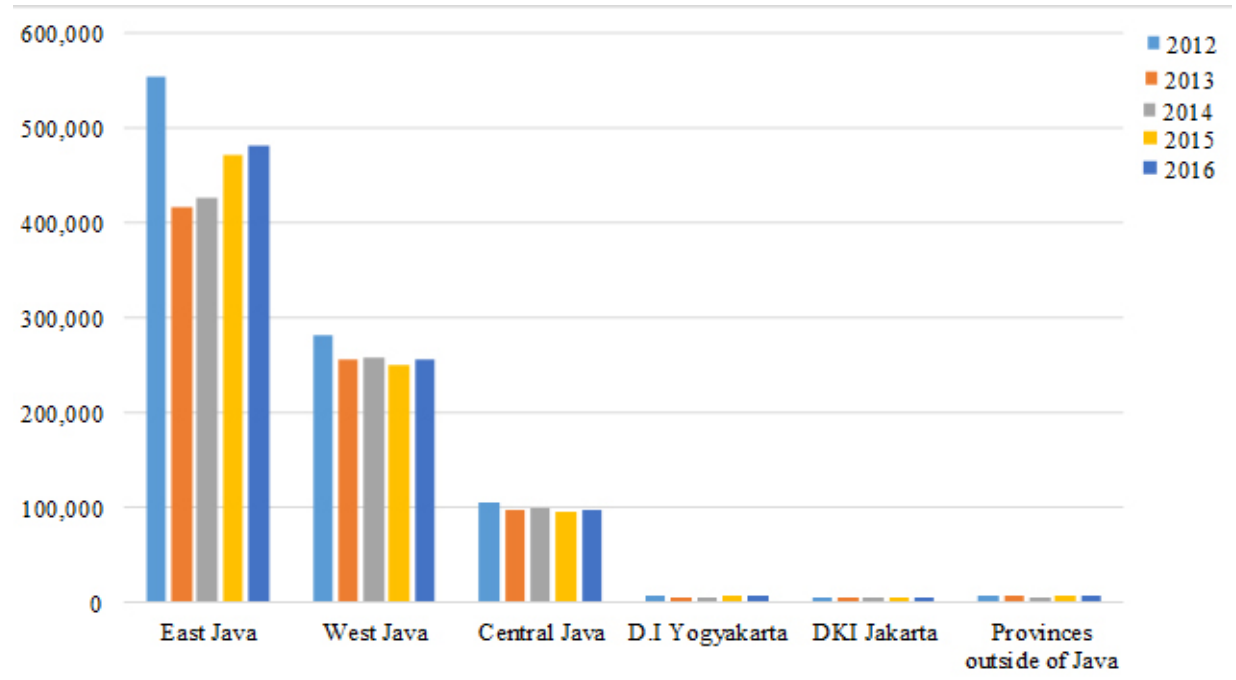

Figure 1. Milk Production in Indonesia from 2012 to 2016 (Directorate General Livestock and Animal Health, Ministry of Agriculture, 2016)

In the dairy industry development in Indonesia, there are several significant obstacles such as resource accession and accessibility, especially for smallscale dairy and small farmers. Small dairy farmers have a high vulnerability of dairy inputs due to lack of owned source of inputs and lands. They used lowcost local inputs with small productivity. They have a high dependency on imported resources to increase their productivity. The use of imported inputs for dairy cattle is unavoidable to increase good quality of milk and high production level (Parikesit, 2005). Based on Shamsuddin \& Podesta (2016), the dairy farmers in Asia are dominated by traditional and small-scale farmers and have limited access to capital and land resources.

The dairy farmers' cooperatives have primarily supported to the Indonesian dairy industry establishment. The development of dairy farmers' cooperatives has a significant impact in the dairy industry development in developing Asia, including in Indonesia. Small dairy farmers got a lot of benefits of the cooperatives development. Some dairy cooperative contributions in the dairy industry are guaranteeing the price of milk from farmers, providing inputs for dairy farmers, providing animal health-care support, developing proper marketing facilities and networks for milk, and guaranteeing farmers' participation in the dairy industry (Shamsuddin, 2016).

Britt et al. (2018) stated that dairy farming will become innovated and modernized in developing countries. Dairy farming with advanced dairy systems to increase milk productivity per cow will grow in developing countries, including Indonesia. The sustainability of the dairy industry influenced by the profitability of dairy farming, genetic improvements of cattle, and good management of inputs. One of the modern dairy farm implementations is utilization of proper equipment for keeping sanitation and quality standards of milk production. In the future, dairy processing will become more specialized and larger to increase the quantity and quality of milk (Britt et al., 2018).

Sustainable business model (SBM) is one of the innovative business model forms. The SBM can be used as tool for a company to achieve long term economic, social, and environmental sustainability (Boons and Ludeke-Freund, 2013). Gallo et al. (2018) also stated that new SBM has the potential for creating not only economic but also social and environmental value on the business. SBM becomes a formula to adapt with the dynamic sustainability challenges. There is a correlation between business models, strategy, and innovation in terms of adaptation to the sustainability context (Gallo et al., 2018). Value creation and delivery, value proposition, and value capture of a business model can be incorporated economic, social, and environmental value in SBM (Schaltegger et al., 2016). Currently, profit companies move towards adopting SBM and incorporate societal and environmental concerns in their business (Stubbs \& Cocklin, 2008; Bocken et al., 2014).

Changing traditional business model strategy to sustainable business model requires strong leadership to incorporate the value, mission, values and business model of the company. The sustainable business 
model need a social-oriented-entrepreneurs with a high commitment to change (Bocken et al., 2016). The differentiation of social entrepreneurship with conventional entrepreneurs is in the value proposition development as the core of the business model (Bocken et al., 2016). Business model transformation needs a close integration between the private sectors, government, academician, local communities and other stakeholders as partners (Bocken et al., 2016). This transformation also raises a challenge for established and new companies on how best to design and distribute products for developing markets to optimize both economic viability, market penetration at scale, and social benefits.

In short, the Government of Indonesia (GoI) was investing substantial resources into the nation's dairy sector, aiming to increase domestic production. Likewise, the private sector was also investing heavily in developing infrastructure and building capacity to improve the growth of the Indonesian dairy sector. However, national dairy sector performance is still not well developed. Therefore, an in-depth study of dairy farming management and business models is needed. The objective of this study is to analyze the comparison between dairy farming management and business model between East Java and West Java, Indonesia.

\section{METHODS}

This dairy farming management and business model study was conducted in Malang, East Java and Lembang, West Java. They were selected purposively with the consideration that the locations were the representative of the two largest milk-producing provinces in Indonesia. In addition, there are farmers group, cooperatives, and milk processors industry in that provinces that are important actors in the dairy industry. The dairy farming management questionnaire survey was conducted in May-July 2016 and the dairy business model survey was conducted in OctoberNovember 2018. The dairy farming management survey respondents were 50 dairy farmers in Malang, East Java and 45 dairy farmers in Lembang, West Java. The dairy business model survey respondents were dairy farmers, cooperatives, and milk processors in East Java and West Java.

Descriptive statistical analysis is used to analyze data by describing data that have been collected without making a general decision (Sugiono, 2011). Data processing in this study used qualitative and quantitative analyses. Quantitative analysis is done by using descriptive analysis, which aims to describe the dairy farming management performance of both in Malang, East Java, and Lembang, West Java. Quantitative data is obtained with dairy farmers' data in both locations. Qualitative data were obtained through interviews and observations for the dairy business model study in East Java and West Java. Lastly, cost and return analysis were conducted to calculate the total return, total cost, and profit or loss of dairy farming.

Figure 2 shows the framework of our research. Firstly, we analyzed the performance of dairy farming by conducting descriptive statistical and cost return analyses. Secondly, we analyzed the inclusive business model of dairy farming by conducting qualitative analysis. Lastly, based on the dairy farming performance and inclusive business model, we suggested managerial implication and recommendation.

\section{RESULTS}

\section{Agribusiness System}

Generally, the agribusiness system of dairy farming in Malang, East Java and Lembang, West Java was not significantly different (Figure 3). Dairy farmers in both locations still practice traditional techniques such as manual milking. No farmers used advanced milking machine yet. Dairy farmers were integrated into downstream of inputs provision such as concentrate feed and cattle breeders from the coops, SAE Pujon Coop at Pujon, Malang, East Java, and KPSBU Lembang at Lembang, West Java.

Dairy farmers were also integrated into up-stream of processing and marketing whereas mostly they sell their fresh milk to the coops and then the coops sell the milk to milk processing industry. Pujon and Malang were the centers of milk production in East and West Java, therefore government puts more attention and agribusiness system is relatively good. Dairy farmers as the members of SAE Pujon are 8.776 farmers, whereas $58 \%$ or 5.072 farmers are actively sell their fresh milk to the coop. Dairy farmers as the members of KPSBU Lembang are 7.190 farmers, whereas $60.36 \%$ or 4.010 farmers are actively sell their fresh milk to the coop. 


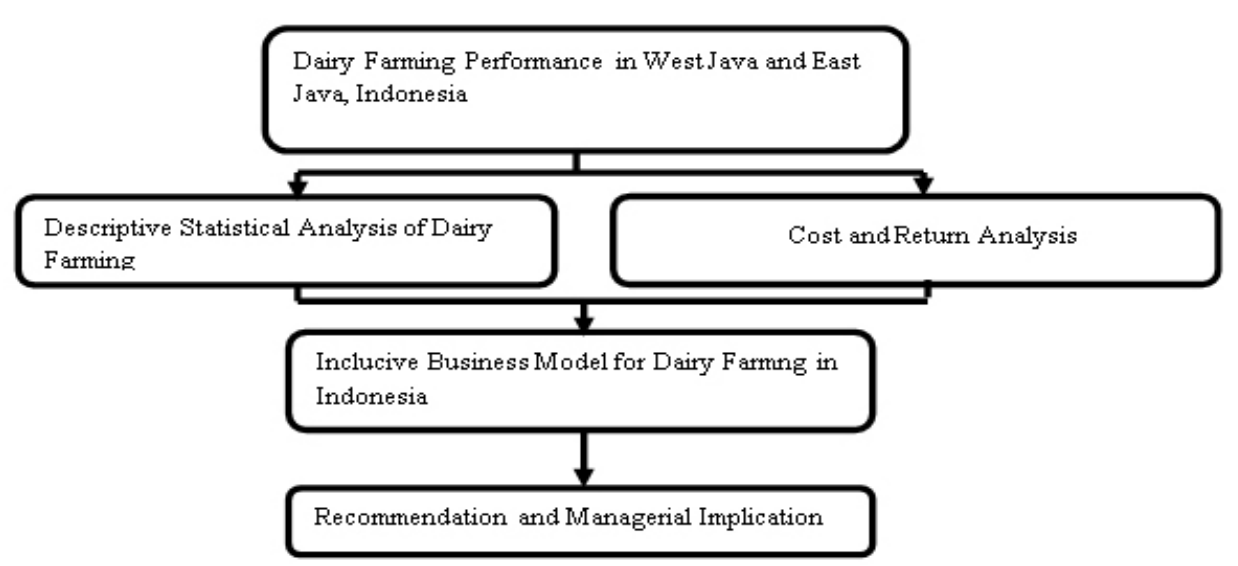

Figure 2. Research framework

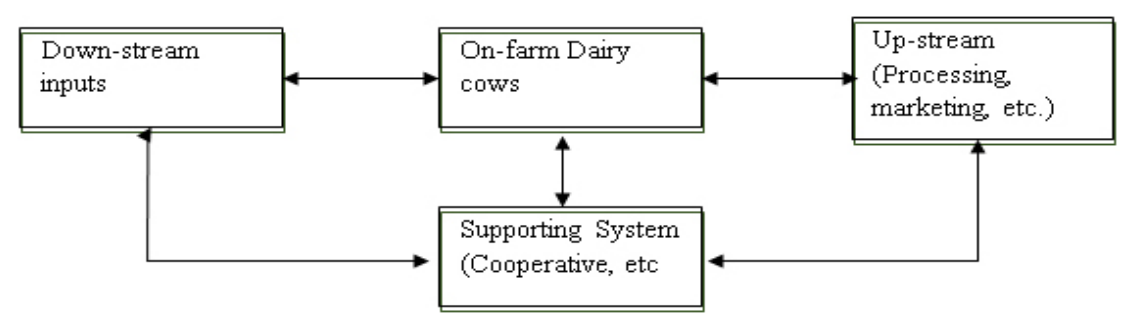

Figure 3. Agribusiness system of dairy farming in Malang and Lembang

West Java and East Java Provinces are the big suppliers for national milk consumption. The milk production is concentrated in East Java and West Java which the population of cattle reached $49.7 \%$ and $22.93 \%$ of the total population in Indonesia, respectively. Milk production has also increased during this four years (2013-2016) by $8,4 \%$ to reach 852.951 tons in 2016 . East Java and West Java Province were the first and the second highest milk producers in 2016. The dairy sector in East Java and West Java contributes substantially to livelihoods especially to smallholder households in rural areas. In general, the dairy value chain in West and East Java Provinces consists of farm input suppliers, farmers, cooperative, milk processors, distributors, retailers, and consumers. The value chain of dairy industry can be seen in Figure 4 .

\section{Characteristics of the Dairy Farmer Respondents}

Based on the survey, the average age of dairy farmers in Malang, East Java (48 years) was older than the average age of dairy farmers in Lembang, West Java (44 years). In addition, average formal education obtained by dairy farmers in Lembang, West Java, is one year longer (slightly more educated) compared to dairy farmers in Malang, East Java. However, in terms of the average dairy farmers in Malang, East Java (22 years), more than 4 (four) years experience compared to dairy farmers in Lembang, West Java (18 years).

Based on the comparative study results, it was also found that the average ownership of lactating cows and average total dairy cattle ownership of dairy farmers in Lembang, West Java was higher than dairy farmers in Malang, East Java. Average ownership of lactating cows of dairy farmers in Lembang, West Java and Malang, East Java were 5.40 heads and 3.32 heads, respectively. The average total dairy cattle ownership of dairy farmers in Lembang, West Java and Malang, East Java were 9.97 heads and 6.32 heads, respectively (Table 2).

\section{Dairy Farming Management Process}

In terms of the dairy farming management process, this session explains the daily activities, amount of feed, productivity and also cost and return analysis. Table 3 shows the daily activities of dairy farming in Malang, East Java and Lembang, West Java. In general, dairy farming activities in Malang and Lembang were similar, such as gathering grass, feeding, cleaning the shed, bathing, and milking. Total hours per day for dairy farming activities in Lembang were higher than in Malang, almost 7 hours and 4.4 hours, respectively, 
due to the total number of dairy cows owned by farmers in Lembang. There are several points that deserve mentioning. Firstly, farmers allocated their time for gathering grass, contributing around $40 \%$ of the total time. As a matter of fact, dairy farmers in Indonesia mostly give feed in the form of fresh grass, whereas they gather the grass every day and give the grass directly without any processing. Secondly, farmers conducted milking twice a day, in the morning and the afternoon.
Milking activities contributed around $21-27 \%$ of dairy activities. Thirdly, every morning, farmers cleaned and bathed the cows before milking, contributing around $17-23 \%$ of total dairy activities. Fourthly, for feeding activities, farmers spent around $13-19 \%$ of total dairy activities. Lastly, farmers also gave medicine or vitamin, artificial insemination and pregnancy test, which are conducted on certain occasions.

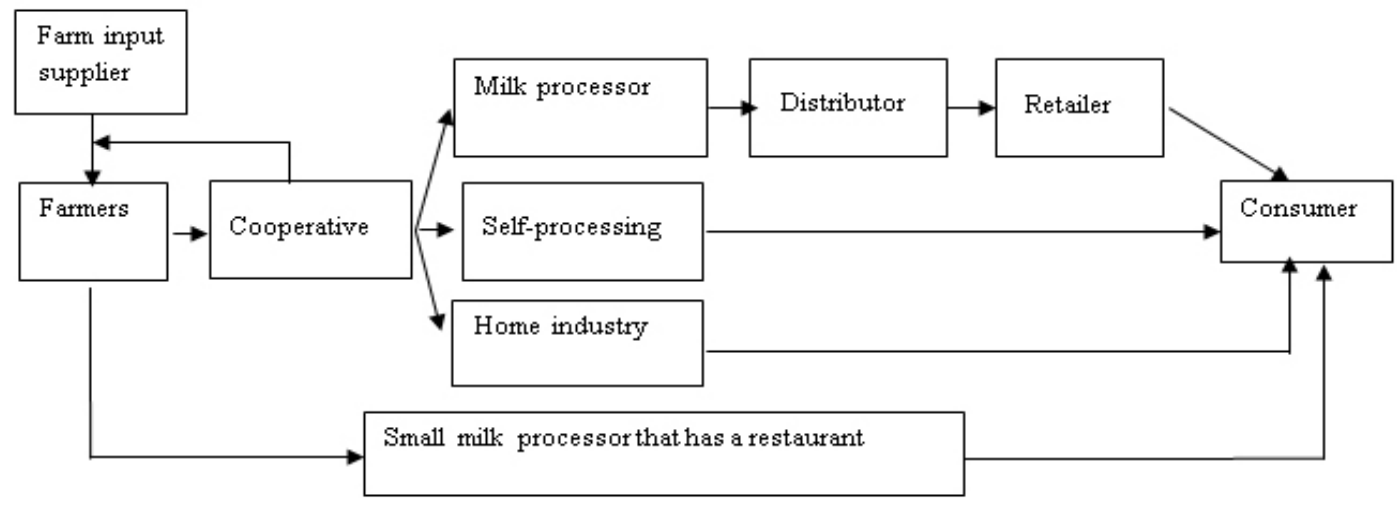

Figure 4. The dairy value chain in West Java and East Java Provinces

Tabel 2. Characteristics comparison of the dairy farmer respondents between Malang, East Java and Lembang, West Java

\begin{tabular}{lcc}
\hline \multicolumn{1}{c}{ Items } & Malang, East Java & Lembang, West Java \\
\hline Number of farmers (persons) & 50 & 45 \\
Age of farmers (years) & 48 & 44 \\
Education attainment (years) & 7 & 8 \\
Dairy farming experience (years) & 22 & 18 \\
Ownership of lactating cows (heads) & 3.32 & 5.4 \\
Ownership of total cattle (heads) & 6.32 & 9.97 \\
\hline
\end{tabular}

Table 3. Daily activities in dairy farming in Malang, East Java and Lembang, West Java

\begin{tabular}{lcccc}
\hline \multirow{2}{*}{$\begin{array}{c}\text { Dairy Activity } \\
\text { (average hour/day) }\end{array}$} & \multicolumn{2}{c}{ Malang, East Java } & \multicolumn{2}{c}{ Lembang, West Java } \\
\cline { 2 - 5 } & hour/day & $\%$ & hour/day & $\%$ \\
\hline Gathering Grass & 1.810 & 41.0 & 2.600 & 37.4 \\
Cleaning the Cowshed & 0.700 & 15.9 & 0.700 & 10.1 \\
Bathing the Cows & 0.150 & 3.4 & 0.890 & 12.8 \\
Feeding the Grass & 0.450 & 10.2 & 0.380 & 5.5 \\
Feeding the Concentrate & 0.370 & 8.4 & 0.520 & 7.5 \\
Milking (Morning) & 0.470 & 10.7 & 0.940 & 13.5 \\
Milking (Afternoon) & 0.440 & 10.0 & 0.920 & 13.2 \\
Giving Medicine/Vitamin & 0.001 & 0.0 & 0.001 & 0.0 \\
Artificial Insemination & 0.009 & 0.2 & 0.006 & 0.1 \\
Pregnancy Check & 0.009 & 0.2 & 0.006 & 0.1 \\
Total & 4.410 & 100.0 & 6.960 & 100.0 \\
\hline
\end{tabular}


In terms of type and amount of feed, all farmers in Malang, East Java and Lembang, West Java gave forage/grass as the largest proportion, amounting to $69.3 \%$ and $36.8 \%$, respectively (Table 4 ). In addition, they also gave concentrate and tapioca waste (onggok) in both locations. There were also differences in terms of feed type, whereas farmers in Malang, East Java gave cassava and rice bran. Meanwhile, farmers in Lembang, West Java gave tofu waste (ampas tahu) and rice straw. These differences might be due to the availability of feed for the cattle.

In terms of productivity, farmers in Malang, East Java produced slightly higher milk production per head per lactation compared to farmers in Lembang, West Java, amounting to 3,471 liters and 3,335 liters, respectively (Table 5). Milk productivity in Malang, East Jawa was 12.83 liter per head per day, that it was slightly lower in Lembang, West Java, as 12.35 liter per head per day. However, milk production per farmer per year was higher in Lembang, West Java, due to the number of cows owned by farmer was higher in Lembang compared to Malang. The lactating period in Malang was longer than in Lembang. The starting age for artificial insemination was earlier in Malang compared to Lembang. The birth ratio was almost the same as fifty-fifty. Service per conception was higher in Malang compared to Lembang.

In order to calculate the profit of dairy farming management, cost and return analysis was employed. The result can be seen in Table 6. The variable costs that we were able to cover in this analysis were feed, family and hired labor. Fixed costs were not able to be covered due to the limited data, whereas most farmers had started for a long time and the property was together with the household. Total return per liter or farm gate price was IDR 4,402 and IDR 4,622 in Malang and Lembang, respectively. In terms of variable costs, feed cost was the highest proportion, contributing around $70 \%$, followed by family and hired labor. In Lembang, West Java, there was a tendency to use more hired labor compared to Malang, East Java. Total variable costs in Malang was IDR 4,503 per liter milk; thus, net return over variable costs was minus IDR 101. However, if the family labor cost included from the calculation, net return became IDR 1,084. In Lembang, total variable costs were IDR 4,609, whereas the net return over variable costs became IDR 14 per liter milk. Meanwhile, when family labor cost was excluded from the calculation, net return became IDR 1,089.
Profitability is the main factor for sustaining the business as well as in dairy farming (van Calker et al., 2005). In this analysis, profitability can be seen in net return over variable costs, contributing $24 \%$ from the milk price when the family labor cost excluded. As a matter of fact, farmers did not calculate family labor as their cost and still continue their dairy farming for decades. In terms of variable costs, feed cost contributed the highest proportion, which is in line with van Calker et al. (2005). Furthermore, the supply and demand of milk also have a strong influence on dairy farming profitability (Britt et al., 2018). Dairy farmers often got lost due to lower revenues than milk production costs. The low price of milk due to the role of middleman become one of the essential factors of the less profitability of small dairy farmers. Another factor of small dairy farmers' less profitability is large quantities of imported powder milk in the domestic market (Shamsuddin \& Podesta, 2016).

As it has been explained above, farmers in both locations practiced dairy farming in traditional ways. Yet, the number of cattle owned farmers were less than ten heads on the average. As Nicholson et al. (2011) and Britt et al. (2018) stated that reducing cost and increasing revenue of dairy farming influenced by specialization of milk processing and modernization of dairy farms, due to the small scale farming, it was quite difficult to modernize the dairy farm in the individual basis. Therefore, business model where farmers can collaborate in a cooperative or be a part of processing industries is important and discussed in the next session.

\section{Dairy Business Model Analysis in East Java and West Java}

Business model can be developed by combination and harmonization of key resources, key partnerships, and key activities on creating value for the customer (Ostelwalder and Pigneur, 2014). Business models consist of three main elements, such as value creation and delivery, value proposition, and value capture. A good business model can bridge the product value proposition and customer needs. Business model development becomes the main factor of successful of an enterprise. The business model can be changed continuously due to adaptation of business environment change, especially due to technological change. In other words, the business model delivers all elements of business in unity in a way to deliver a value proposition to the customer segments (Ucaktürk, 2011). 
Table 4. Types and amount of feed of dairy farming in Malang, East Java and Lembang, West Java

\begin{tabular}{lcccc}
\hline \multirow{2}{*}{ Feed Items } & \multicolumn{2}{c}{ Malang, East Java } & \multicolumn{2}{c}{ Lembang, West Java } \\
\cline { 2 - 5 } & $\mathrm{kg} / \mathrm{h}$ ead/day & $\%$ & $\mathrm{~kg} / \mathrm{h}$ ead/day & $\%$ \\
\hline Concentrate & 2.2 & 5.1 & 7.3 & 11.1 \\
Forage/Grass & 30.0 & 69.3 & 24.3 & 36.8 \\
Cassava & 1.0 & 2.3 & 0.0 & 0.0 \\
Tapioka Waste (Onggok) & 5.6 & 12.9 & 8.7 & 13.2 \\
Rice Bran & 4.5 & 10.4 & 0.0 & 0.0 \\
Tofu Waste (Ampas Tahu) & 0.0 & 0.0 & 15.0 & 22.7 \\
Rice Straw & 0.0 & 0.0 & 10.7 & 16.2 \\
Total & 43.3 & 100.0 & 66.0 & 100.0 \\
\hline
\end{tabular}

Table 5. The productivity of dairy farming in Malang, East Java and Lembang, West Java

\begin{tabular}{lccc}
\hline \multicolumn{1}{c}{ Items } & Units & Malang, East Java & Lembang, West Java \\
\hline Milk Production & Liter/farmer/year & 13,040 & 18,418 \\
Milk Production & Liter/head/lactation & 3,471 & 3,335 \\
Productivity & Liter/head/day & 12.83 & 12.35 \\
Lactating Period & Days & 300 & 270 \\
Starting Age to Artificial Insemination & Months & 14 & 18 \\
Birth Ratio & Male:Female & $55: 45$ & $53 ; 47$ \\
Service per Conception & S/C & 3 & 2 \\
\hline
\end{tabular}

Table 6. Cost and return analysis of dairy farming in Malang, East Java and Lembang, West

\begin{tabular}{lcccc}
\hline & \multirow{2}{*}{ Items } & \multicolumn{2}{c}{ Malang, East Java } & \multicolumn{2}{c}{ Lembang, West Java } \\
\cline { 2 - 5 } & $(\mathrm{Rp} /$ liter $)$ & Percentage & $(\mathrm{Rp} /$ liter $)$ & Percentage \\
\hline Return milk output & 4,402 & & 4,622 & \\
Variable costs & & & & \\
a. Feed & 3,263 & 72.46 & 3,332 & 72.30 \\
b. Family labor & 1,185 & 26.31 & 1,075 & 23.33 \\
c. Hired labor & 56 & 1.24 & 202 & 4.37 \\
Total variable cost & 4,503 & 100.00 & 4,609 & 100.00 \\
\hline Net return over variable cost (NROVC) & -101 & & 14 & \\
NROVC (Family labor excluded) & 1,084 & & 1,089 & \\
\hline
\end{tabular}

Innovation of business model will be more effective and sustainable than the innovation of products or services. Innovation of business model is needed for the enterprise to face a new disruptive technology, a volatile market, an uncertainty in new market, and a stagnancy of economic. Business model innovation not only how to create the new products or services, but also how to synthesize different strong elements than the competitors' to make new value proposition of the business or enterprise for their customers (Ucaktürk, 2011).
As an individual farmers cannot modernize or specialize; therefore, business model became important for farmers to be a part of it. Based on field study, there are six dairy business model in East Java and West Java (Table 7), namely: 1) integrated processor -driven extension work, 2) KUD driven collection and extension, 3) privately run MCPs, 4) vertically integrated farm and processor working with smallholders, 5) small-scale processing direct to consumer, and 6) large scale, vertically integrated. Each dairy business model has different criteria in terms of the impact on quality and volume of supply, improving viability (particularly smallholders), and characteristics. 


\begin{tabular}{|c|c|c|c|c|c|}
\hline \multirow[b]{2}{*}{ Type } & \multirow[b]{2}{*}{ Model } & \multicolumn{4}{|c|}{ Comparison } \\
\hline & & Example & $\begin{array}{l}\text { Impact on quality } \\
\text { and volume of } \\
\text { supply }\end{array}$ & $\begin{array}{l}\text { Improving } \\
\text { viability, } \\
\text { particularly } \\
\text { smallholders }\end{array}$ & Characteristics \\
\hline 1.0 & $\begin{array}{l}\text { Integrated } \\
\text { processor -driven } \\
\text { extension work }\end{array}$ & Nestle & High & High & $\begin{array}{l}\text { Private investment-driven (a positive } \\
\text { if private companies commit to } \\
\text { investment, a negative, if companies } \\
\text { require incentives to invest) }\end{array}$ \\
\hline 2.0 & $\begin{array}{l}\text { KUD driven } \\
\text { collection and } \\
\text { extension }\end{array}$ & $\begin{array}{c}\text { KUD } \\
\text { Pangelangan }\end{array}$ & High & High & $\begin{array}{l}\text { Built on government-funded grant } \\
\text { programs (mainly Dutch government) }\end{array}$ \\
\hline 3.0 & $\begin{array}{l}\text { Privately run } \\
\text { MCPs }\end{array}$ & Greenfields & Low-med & Low-med & $\begin{array}{l}\text { Tend not to have in-built extension } \\
\text { programs, Opportunity to integrate } \\
\text { with other CSR programs }\end{array}$ \\
\hline 4.0 & $\begin{array}{l}\text { Vertically } \\
\text { integrated farm } \\
\text { and processor } \\
\text { working with } \\
\text { smallholders }\end{array}$ & $\begin{array}{l}\text { Cimory, PT } \\
\text { Ultrajaya }\end{array}$ & Med-high & Med & $\begin{array}{l}\text { Appears to be effective if integrated } \\
\text { into a vertically integrated farm } \\
\text { strategy, so not as compelling on a } \\
\text { stand-alone basis. }\end{array}$ \\
\hline 5.0 & $\begin{array}{l}\text { Large scale, } \\
\text { vertically } \\
\text { integrated }\end{array}$ & Greenfields & High & Low & $\begin{array}{l}\text { No incentive to work with smallholders } \\
\text { other than to broaden own market } \\
\text { capacity, with capital investment. }\end{array}$ \\
\hline 6.0 & $\begin{array}{l}\text { Small-scale } \\
\text { processing direct } \\
\text { to consumer }\end{array}$ & $\begin{array}{l}\text { Susu Mbok } \\
\text { Dharmi }\end{array}$ & Low & Low & $\begin{array}{l}\text { Difficult to scale, and risks quality } \\
\text { issues; But demonstrates opportunity } \\
\text { in market for small-scale operators } \\
\text { working closely with farmers. }\end{array}$ \\
\hline
\end{tabular}

Integrated processor-driven smallholder extension and improvement

This type has a good impact on increasing the quality and volume of milk supply. PT Nestle has already implemented this business model, especially in East Java Province. PT Nestle improves the viability of small dairy farmers. This business model needs private investment-driven from milk processing industry. It has a positive impact if private companies commit to investment and also have a negative impact if companies require big incentives to invest.

\section{KUD or cooperative driven collection and extension}

KUD becomes essential and center of this business model type. KUD plays a role as a milk collector for processors. KUD was established Milk Collection Point and cooperation with processors (such as PT Cimory and PT Ultrajaya in West Java). The dairy business model also can be integrated grant-funded improvement program (such as PT Frisian Flag Indonesia). This business model has impact on increasing quality and quantity of milk supply and significantly improves the viability of smallholders. The business model has already established based on government-funded grant programs (mainly since Dutch government in Indonesia).

Private collection points and distribution to processors

Milk collection points on this dairy business model built from private business initiation. Milk collection point establishment can come from the corporate social responsibility (CSR) program. This business model tends not to have in-built extension programs. PT Greenfields (East Java) has been already implemented this business model. Milk collection point distributes milk directly to milk processors with certain quality standards. This business model has a low-medium impact on the quality and quantity of milk and improvement of smallholders' viability.

Verticallyintegratedfarmandprocessor-complementing existing smallholder connections

Milk processors have vertical integration with existing small dairy farmers or dairy farmer groups. PT Cimory and PT Ultrajaya have been already implemented this business model in cooperation with dairy farmers in 
West Java. This business model is more effective if implemented into a vertically integrated farm strategy than as compelling on a stand-alone basis strategy. It has a medium-high impact on increasing the quality and quantity of milk supply and medium impact on improving smallholders' viability.

Large scale farm supply (exclusive of smallholder farmers)

PT Greenfields is one of the role models of large scale farm supply business models. PT Greenfields established two big dairy farms in Malang, East Java. There is no incentive to work with smallholders other than to broaden their own market capacity with capital investment. This business model very exclusive for smallholder farmer involvement. It has a low impact on improving smallholder's viability. It more focused on increasing quality and quantity of milk supply.

Small-scale processing and sale direct to consumer

The characteristics of this business model are difficult to scale-up, have risks of quality issues, demonstrates opportunity in the market for small-scale operators working closely with farmers. Susu Mbok Dharmi is one of the role model small-medium enterprises (SME) for this business type. Susu Mbok Dharmi has collaborated with dairy farmer groups in West Java. Susu Mbok Dharmi directly selling their milk product to consumers.

Based on these six types of business model and considering the analysis of dairy farming performance and existing condition whereas they are the members of cooperatives, business model 2 (KUD or the cooperative driven collection and extension) should be given emphasis in order to increase the dairy performance as well as to increase dairy farmers' bargaining position. Several points deserve mentioning. Firstly, dairy farmers will have a chance to perform cost efficiency by purchasing inputs from cooperatives, expecting to increase the profit of farmers. Secondly, since dairy farmers are practicing traditional technology, cooperative can be the agent of extension for better dairy farming management, for instance, feed management that related to the production of milk. On the other hand, dairy farmers should be open to new technology. Thirdly, farmers run their dairy farming in small-scale condition; thus, by joining cooperative, they will have a better bargaining position rather than an individual farmers. Finally, cooperative will help farmers to buy their milk, assuring the marketing of their milk.

\section{Managerial Implications}

Increasing Dairy Farming Productivity and Income

Based on the results in farm management performance, there are two possible managerial implications at the dairy farmers level, i.e. increasing productivity and income. Firstly, there is possibility to increase milk productivity. BPS (2016) mentioned that the average milk productivity per headperday in Indonesia was 16.19 liter, as mentioned earlier the average milk productivity of dairy farmers was 12.83 and 12.35 liters in Malang and Lembang, respectively. Therefore, there are still possibility to increase milk productivity. According to Adinegoro et al. (2017) and Larasati (2016), feed was the significant factor in increasing milk production. Dairy farmers in the study area diversed in feeding, mostly based on the availability in the area and the traditional way. Hence, feed management is better to introduced to dairy farmers, including the composition of feed, time and amount of feed application. Secondly, there is a possibility to increase dairy farming income. Increasing dairy farming productivity will lead to increasing dairy farming income. However, there is also the possibility of increasing cost-efficiency. As mentioned above, all farmers are the member of cooperative which can supply inputs to dairy farmers whereas can be more cheaper than buying individually.

Improving Effeciency of Integrated Agribusiness System

In terms of business model, business model cooperative driven collection and extension can be more utilized for increasing the performance of dairy farmers as wel as being integrated with the down-stream and up-stream agribusiness system. The cooperative can introduce new technology to the dairy farmers, for instance, feed management that can increase milk production. Accordingly, dairy farmers should also open to the new technology. By joining cooperative, dairy farmers will have a better bargaining position. This cooperative should be functioning efficiently in order to support the dairy farmers. 


\section{CONCLUSIONS AND RECOMMENDATIONS}

\section{Conclusions}

In terms of the agribusiness system, dairy farming is integrated into down-stream and up-stream, whereas cooperative plays an important role. In terms of farming scale, the average cows' ownership is relatively low, less than ten whereas the lactating cows around 50 percent. The productivity of milk production is around 12 liters per head per day. In terms of cost, feed cost occupied the largest proportion. Dairy farmers earned around 20 percent over cash cost. There are six inclusive business models (IBMs) between smallholder farmers, cooperatives, and private companies with different characteristics that have been implemented in East Java and West Java.

Based on dairy farming and business model analyses, as the majority of dairy farmers in both provinces are members of cooperative, business model cooperative driven collection and extension can be more utilized for increasing the performance of dairy farmers. Firstly, as the agent of extension, the cooperative can introduce new technology to the dairy farmers, for instance, feed management that can increase milk production. Accordingly, dairy farmers should also open to the new technology. Secondly, cooperative can supply inputs to dairy farmers as well as buy their milk production, implying for cost efficiency and ensuring milk marketing. Lastly, by joining cooperative, dairy farmers will have a better bargaining position.

\section{Recommendations}

It is suggested that cooperative improve its role in the integrated agribusiness system in order to improve the bargaining position of dairy farmers as well as in terms of cost-efficiency. The strategies and policies should be implemented to support the development of sustainable, profitable, and smallholder-inclusive dairy supply chains in East Java and West Java.

\section{REFERENCES}

Adinegoro A, Daris A, Zulmanery. 2017. Faktorfaktor yang mempengaruhi produksi sapi perah kelompok tani ternak sapi perah (KTTSP) Kania, Kabupaten Bogor. Jurnal Agribisnis 11(4): 148160.
Bocken NMP, Fil A, Prabhu J. 2016. Scaling up social businesses in developing markets. Journal of Cleaner Production (2016). https://doi. org/10.1016/j.jclepro.2016.08.045.

Bocken NMP, Short SW, Rana P, Evans S. 2014. A literature and practice review to develop sustainable business model archetypes. Journal of Cleaner Production 65: 42-56. https://doi. org/10.1016/j.jclepro.2013.11.039.

Boons F, Ludeke-Freund F. 2013. Business models for sustainable innovation: state-of-the-art and steps towards a research agenda. Journal of Cleaner Production 45 (2013): 9-19. https://doi. org/10.1016/j.jclepro.2012.07.007.

BPS. 2016. Statistik Perusahaan Peternakan Sapi Perah. Jakarta: BPS.

Britt JH et al. 2018. Invited review: Learning from the future A vision for dairy farms and cows in 2067. Journal Dairy Science 101: 3722-3731. https:// doi.org/10.3168/jds.2017-14025.

Gallo PJ, Lopez RA, Montiel I. 2018. Associative Sustainable Business Models: Cases in the beanto-bar chocolate industry. Journal of Cleaner Production 174 (2018): 905-916. https://doi. org/10.1016/j.jclepro.2017.11.021.

Larasati DA. 2016. Faktor yang berpengaruh terhadap produktivitas susu sapi perah di Desa Geger Kecamatan Sendang Kabupaten Tulungagung. Jurnal Geografi 14(1): 34-41.

Nicholson CF, Gomez MI, Gao OH. 2011. The costs of increased localization for a multiple-product food supply chain: Dairy in the United States. Food Policy 36(2011): 300-310. 10.1016/j. foodpol.2010.11.028.

Osterwalder A, Pigneur Yves. 2014. Business Model Generation. Alih bahasa oleh Natalia Ruth Sihandrini. Jakarta: PT Elex Media Komputindo.

Parikesit et al. 2005. Resource analysis of small-scale dairy production system in an Indonesian village a case study. Agriculture, Ecosystems, and Environment 105(2005): 541-554. http://doi. org/10.1016/j.agee.2004.07.013.

Riethmuller $\mathrm{P}$ et al. 1999. The mixing ratio in the Indonesian dairy industry. Agricultural Economics 20 (1999): 51-56.

Schaltegger S, Ludeke-Freund F, Hansen EG. 2016. Business models for Sustainability: a co-evolutionary analysis of sustainable entrepreneurship, innovation, and transformation. Organization \& Environment 29(3): 264-289. 
https://doi.org/10.1177/1086026616633272.

Shamsuddin M, Podesta MG. 2016. Dairy Production in

Diverse Regions: Southern Asia. Food Sciences

Elsevier 2: 750-758. http://dx.doi.org/10.1016/ B978-0-08-100596-5.00715-0.

Stubbs W, Cocklin C. 2008. Conceptualizing a 'sustainability business model'. Organization \& Environment 21:103-127. https://doi. org/10.1177/1086026608318042.

Ucaktürk A, Bekmezci M, Ucaktürk T. 2011. Prevailing During the Periods of Economical Crisis and Recession through Business Model Innovation.
Procedia Social and Behavioral Sciences 24(2011): 9-100. http://doi.org/10.1016/j. sbspro.2011.09.095.

Umberger W, Granzin B, Permani R, Ritchie Z. 2016. Improving milk supply, competitiveness and livelihoods in smallholder dairy chains in Indonesia. ACIAR: Australia.

van Calker KJ, Berentsen PBM, Giesen GWJ, Huirne RBM. 2005. Identifying and ranking attributes that determine sustainability in Dutch dairy farming Agric. Human Values 22(2005): 53-63. 10.1007/s10460-004-7230-3. 